This is a peer-reviewed, accepted author manuscript of the following research article: Gillies, L. (2011). I. Clarifying the philosophy of article 15 in the Brussels I regulation: C-585/08 Peter Pammer v Reedere Karl Schluter GMBH \& co and C144/09 hotel alpenhof Gesmbh v Oliver Heller. International and Comparative Law Quarterly, 60(2), 557-564. https://doi.org/10.1017/S002058931100011X

\title{
I. CLARIFYING THE 'PHILOSOPHY OF ARTICLE 15' IN THE BRUSSELS I REGULATION: C-585/08 PETER PAMMER V REEDERE KARL SCHLUTER GMBH \& CO AND C-144/09 HOTEL ALPENHOF GESMBH V OLIVER HELLER
}

\section{A. Introduction}

In the Cases C-585/08 Peter Pammer v Reedere Karl Schluter GmbH \& Co and C-144/09 Hotel Alpenhof GesmbH $v$ Oliver Heller, the CJEU considered the applicability of Article 15(1) (c) of Regulation EC 44/2001 (Brussels I) vis-à-vis the use of web sites in commercial communications with consumers domiciled in other Member States. Article 15 of Brussels I contains special rules which determine the jurisdiction of disputes concerning 'protected' 1 consumer contracts falling within its scope. Articles 15(1)(a) and (b) apply where either the contract is subject to an instalment credit arrangement or where the contract is for a loan to finance the sale of goods respectively. These two recent cases were concerned with Article 15(1)(c), itself previously regarded by the Commission as the 'philosophy of Article 15.'2 The connecting factors in Article 15(1)(c) apply in two situations. ${ }^{3}$ The first is where the seller concludes contracts as a result of commercial activities entered into in the Member State of the consumer's domicile. The alternative applies when a business 'directs' its professional or commercial activities to the Member State of the consumer's domicile and a contract is concluded as a consequence of those activities. Article 15(2) also (currently) provides that a non-EU defendant corporation which has a branch or agency in a Member State that contracts with a consumer may be regarded as domiciled in that Member State. The cases are important as for the first time references were made to the CJEU to specifically consider and interpret the extent to which a business' web site should be construed as 'directing [commercial] activities' towards consumers domiciled in other Member States. Essentially, what kind of activity should be construed as directing activity when a seller or his agent uses a web site with the intention to facilitate contractual activities with consumers located in a Member State?

\section{B. Facts}

There were two issues to be considered by the courts in these cases. In Mr Pammer's case, as a consumer buyer resident in Austria, he entered into a contract with a German company after perusing its agents' web site for a holiday which, he alleged, neither met the description on the intermediaries' web site nor his expectations. The Austrian agent returned part of the full payment, so $\mathrm{Mr}$ Pammer sued for the balance. The Austrian national court made no determination as to whether the contract constituted a package travel arrangement. Furthermore, it was not clear whether the email correspondence between Mr Pammer and the agent had been sufficient to establish jurisdiction in Austria. Essentially, to what extent had there been an alignment of commercial activities between the German company, its

1 Bertrand v Ott [1978] ECR 1431 ; P Stone, EU Private International Law, (Edward Elgar, Cheltenham, 2006) 122 . See generally DJB Svantesson, Private International Law and the Internet (Kluwer Law International, The Hague, 2007); L Gillies, Electronic Commerce and International Private Law, A Study of Electronic Consumer Contracts, (Ashgate, Aldershot, 2008); J Hill, Cross-Border Consumer Contracts (OUP, Oxford, 2008); S Tang, Electronic Consumer Contracts in the Conflict of Laws (Hart, Oxford, 2009); P Cachia, 'Consumer contracts in European private international law: the sphere of operation of the consumer contract rules in the Brussels I and Rome I Regulations' (2009) 34EL Rev 3476 ; F Wang, Internet Jurisdiction and Choice of Law, Legal Practices in the EU, US and China (CUP, Cambridge, 2010).

${ }^{2}$ COM (1999) 348 FINAL 99/0154 (CNS), 14/07/99, 16 ; Gillies (n 1$) 88$ ff.

3 J Øren, 'International Jurisdiction Over Consumer Contracts in e-Europe' (2003) 52 ICLQ 665. 
intermediary and the ensuing contract with Mr Pammer via the agent's web site? The Austrian court upheld jurisdiction on the basis that the agent's website advertised the German company's services in Austria. The German company appealed and was successful. $\mathrm{Mr}$ Pammer subsequently appealed to the Austrian Supreme Court which referred the case to the CJEU on two grounds, the first being whether the contract for a freight voyage was a package travel contract and the second whether the provisions of Article 15(1)(c) and (2) applied when the Austrian consumer contracted with a German company via an agent's website which was accessible to residents in Austria.

In the case of Hotel Alpenhof, Mr Heller was a consumer domiciled in Germany who contracted to use the accommodation and services of the hotel in Austria. The contract between the parties had been entered into at a distance via the company's website, the email address of the hotel being available on its website. The hotel alleged that Mr Pammer failed to pay for the services he had consumed and raised proceedings in Austria for the balance. $\mathrm{Mr}$ Heller claimed that he should be sued, as a consumer, not in Austria but in Germany under Article 16(2) of the Brussels I Regulation.

\section{The Issues: What Constitutes a 'Package Travel Contract' and When are Website Activities 'Aligned' Towards Consumers in Different Member States?}

The first issue, applicable to the Pammer case, was whether the contract between a German company via its intermediary (also based in Germany) and Mr Pammer (an Austrian resident) for a 'freight voyage' 4 contract from Italy to the Far East constituted a 'package travel' [consumer] contract under Article 15(3) of the Brussels I Regulation. The Austrian Supreme Court took the view that if it did constitute the equivalent of a cruise, the Austrian court would be able to assert jurisdiction. ${ }^{5}$ Accordingly, a reference was sought by the Supreme Court to the CJEU. The second issue, common to both cases, ${ }^{6}$ was whether there had been a prior 'alignment' of commercial activities in accordance with Article 15(1)(c) of the Brussels I Regulation to establish jurisdiction in each of the Member States where the consumers were domiciled. In both cases, did the fact that the consumers accessed the sellers' website and concluded a contract either via a web site (in the case of Alpenhof) or an exchange of emails and subsequent postal booking (in the case of Pammer) both be construed as 'directed activities' towards the Member States where each consumer was domiciled? The reasoning from the Advocate General in both cases, now affirmed by the CJEU, gives some indication of the basis upon which a national court will now have to determine from the facts of the case whether a business has directed its activities to consumers in those Member States via the use of advertisements such as websites (analogous with traditional TV and radio advertisements). However, if an autonomous interpretation of the 'directing such activities' connecting factor in Article 15(1)(c) is to be achieved, the CJEU must still provide clarity in determining the extent to which jurisdiction and choice of law ${ }^{7}$ are established as a 'threshold requirement' 8 when a business uses a web site to align, direct or target its activities at consumers in other Member States. Such guidance will assist not just in the harmonious interpretation of the Brussels I Regulation as it currently operates, but may have significant effects if and when any future proposed replacement of the Regulation is enacted and becomes directly relevant to businesses domiciled outside the EU operating websites and contracting with EU

\footnotetext{
${ }^{4}$ Judgment of the Court (Grand Chamber) C-585/08 and C-144/09, 7 December 2010, para 14.

5 ibid para 22.

6 ibid para 32.

${ }^{7}$ Art 6, Regulation EC 593/2008, Rome I.

${ }^{8}$ Standard Bank London Ltd v Dimitrios and Styliani Apostolakis (No2) [2001] Lloyd's Law Reports 240, 248.
} 
consumers who may wish to sue them in a Member State on the basis of a modified version of Article $15(1)(\mathrm{c}){ }^{9}$

\section{The 'Directed Activities' Connecting Factor}

The rule, subject to particular criteria, that consumers have the ability to raise proceedings against a seller in their own jurisdiction has been enshrined in EC law since Article 13 of the Brussels Convention 1968. The requirements of Article 13 of the Brussels Convention were considered by the English Court of Appeal in Rayner v Davies. ${ }^{10}$ The CJEU and UK courts have confirmed the restricted ${ }^{11}$ scope of Article 13 operated to protect only private, final consumers contracting for their own private use or consumption ${ }^{12}$ provided there is a sufficient connection between the contract and the consumer's domicile. ${ }^{13}$ Previously, Article 13 required that the consumer had to conclude the contract with the business whilst present in their jurisdiction. However, this requirement was rightly abolished by Article 15 of Brussels I. With the advent of the mobile or active consumer and the increasingly prevalent use of third generation technologies, it must be demonstrated that a business aligned or sought to link its commercial activities towards consumers in different Member States. Advocate General Trstenjak also provided the opinion in Ilsinger $v$ Dreschers ${ }^{14}$ where it was confirmed that if a consumer contract has been concluded, the consumer is entitled to claim a prize (for example, a 'free gift') promoted before the contract was entered into between the parties. The prize need not have been conditional upon ordering the goods. Essentially, therefore, the ethos behind both Article 13 of the Brussels Convention and Article 15(1)(c) of the Brussels I Regulation is that the seller's commercial activity-however pursued-must enable a contract to be concluded with a consumer as a result of those activities.

\section{E. Analysis of AG Findings}

In the instant cases the Advocate General repeated that regardless of the means of communication between a seller and a consumer, for jurisdiction to be established under Article 15(1)(c), the case of Ilsinger ${ }^{15}$ stated that it is a core requirement that the seller's commercial activities must enable a contract to be concluded when the parties are at a distance to one another. In order to achieve this, the Advocate General said that it was necessary to clarify two important aspects. First, whether the mere accessibility of a website was sufficient for Article 15(1)(c) and second whether the necessity to distinguish cases where the seller uses a rudimentary website (ie passive websites simply providing information and offering no means of direct communication with consumers) in comparison to web sites that facilitate, pre, during and post-contractual steps (advertising, offer and acceptance, order/delivery confirmation and receipt of payment respectively). The Advocate General confirmed that four conditions were necessary for the operation of Article 15(1)(c).

\footnotetext{
${ }^{9}$ Noting the current effect of Article 15(2) upon non-EU based corporations. See the recent proposal by the Commission for the replacement of the Brussels I Regulation: COM (2010) 748 FINAL, 2010/0383 (COD), 14 December 2010 which, inter alia, proposes to 'Europeanise' Member States' residual jurisdiction for the benefit of EU consumers. At the time of writing, no substantive changes appear to be proposed vis-à-vis Article 15. ${ }^{10}$ [2003] 1 All ER (Comm) 394 (CA).

${ }^{11}$ A Briggs and P Rees, Civil Jurisdiction and Judgments, (2 ${ }^{\text {nd }}$ edn, LLP, London, 1997) 60.

${ }^{12}$ Bertrand v Ott [1978] ECR 1431, Shearson Lehmann Hutton Inc. v TVB [1993] ECR I-139 and Standard Bank London Ltd v Dimitrios and Styliani Apostolakis (No 1) [2000] IL Pr 7661431 (cf BJ Mann (Advertising) Ltd v Ace Welding \& Fabrications Ltd 1994 SCLR 763 overruled in Prostar Management Ltd v Twaddle 2003 SLT (Sh Ct) 11).

${ }^{13}$ C-96/00 R. Gabriel v Schlanck \& Schick GmbH [2002] ECR I-6367.

${ }^{14} \mathrm{C}-180 / 06$ Renate Ilsinger $v$ Martin Dreschers (administrator in the insolvency of Schlank \& Schick GmbH) 2009/C 153/05.

15 ibid.
} 
The first requirement was for the 'completion of a contract', which the Advocate General regarded as a matter for the national court to determine on the facts. The second condition was that the contract had to have been between a professional seller (as defined by Article 15) and a consumer. Again, the national court would have to be satisfied that the parties met those definitions. The Brussels I Regulation helpfully defines the nature of the seller in a consumer contract and the cases deriving from Article 13 of the Brussels Convention referred to earlier make it abundantly clear that Article 15 only operates in favour of private, final consumers. The third requirement was that the contract falls within the scope of the business' professional or commercial activities. Again, the Advocate General confirmed that it is for the national courts to assess this on the evidence provided to them. Finally, the fourth requirement was that the business has pursued professional activities in the Member State where the consumer is domiciled (for example, by physical presence or instructing an agent) or 'directs' such activities there (for example, using appropriately targeted technological means to conclude contracts with consumers in different jurisdictions). It is the last requirement which the Advocate General sought to provide definitive criteria for the national courts to apply in determining whether they have jurisdiction under Article 15(1)(c) and is the basis upon which the effective application of Article 15(1)(c) hinges.

In asserting the criteria regarded as crucial for national courts to apply in establishing 'directed activity' under Article 15(1)(c), the Advocate General considered a number of different interpretative approaches. These included the grammatical approach, the literal or ordinary meaning, a teleological/uniform approach, an historical ${ }^{16}$ approach and a systematic (or 'criterion') approaches. The literal approach was discounted as article 15 itself did not make a distinction between different websites based on their levels of interactivity. This is indeed correct, for website technology and consumer accessibility of websites have both moved apace since the enactment of the Regulation. Interestingly, the Advocate General sought to distinguish the teleological/uniform approach as, in her opinion, it operated after the adoption of the Rome I Regulation and (given what has been said before) it could not be used to differentiate spectra of web activities. The reference to the historical approach seemed to indicate that in line with article 13 of the Brussels Convention, websites had to constitute 'advertising' in the consumer's Member State for jurisdiction to be established. However, websites are different to traditional means of advertising in that they are instantaneous, dematerialised and act as a means of both communicating and contracting with consumers. Instead, the remaining approaches were combined to formulate the following criteria to be used by the national courts.

The Advocate General remarked that from the Recital of the Regulation, it was feasible that any accessible website would lead to the application of article 15 . However, the Advocate General was not persuaded that such an interpretation would be in line with a uniform, autonomous interpretation. As a consequence, she maintained it would not (in view of the wording of the article) be necessary to distinguish literally between different spectra or categories of websites, an approach taken and modified by the US courts. ${ }^{17}$ In the context of websites as directed commercial activities, her opinion suggests that the web site must be sufficiently developed to target consumers in those jurisdictions with a view to contracting at a distance with them. The nature and content of the website at the time the contract was concluded with the consumer would therefore be one factor for the national court to consider in determining whether the business' commercial objectives were targeted towards consumers in discrete jurisdictions. The Advocate General suggested that such information as

\footnotetext{
${ }^{16}$ Referring to the original proposal, the EESC opinion, the revision and the Statement on art 15.

${ }^{17}$ Derived from Zippo Manufacturing v Zippo Dot Com. Inc, 952 F.Supp, 1119 (W.D. Pa. 1997), subsequently adapted by the Supreme Court in ALS Scan v Digital Service Consultants Inc, 537 U.S. 1105 (2003) and Bates v Starnes 2005 WL 705345 (D.Md.), 24 March 2005.
} 
the businesses' knowledge of prior contracts with consumers in those jurisdictions and their intentions to contract with such consumers at a distance would be relevant, as would information on the website itself such as international dial codes and services (whether instantaneous or continuous) were tailored for consumers from the Member State in question. To that extent, the Advocate General agreed with the earlier opinion from the Commission that the provision of an email address by a business on its website would not meet the threshold criteria. Furthermore, the Advocate General was of the opinion that it would be necessary to consider (though not exclusively so) both the language(s) and the domain name(s) used by the business in its website as part of the overall indication to intentionally target commercial activities to consumers in different Member States. Interestingly, the Advocate General confirmed that if a seller chose to send unsolicited emails to consumers in different jurisdictions and contracts were concluded as a result, the business should be capable of being sued in those jurisdictions. The Advocate General suggested that, in line with Oren's view, ${ }^{18}$ businesses should be permitted to ring-fence their activities just in the same way as opting to positively targeting particular jurisdictions for commercial purposes.

\section{F. The Decision of the ECJ}

On 7 December 2010, the Grand Chamber of the CJEU issued its decision in these conjoined cases. Returning to the first issue, namely whether the contract between Mr Pammer and the German company constituted a package travel contract, the Grand Chamber affirmed that it did, being satisfied that this voyage included at least three of those aspects (travel, accommodation, length of voyage, tourist services) necessarily analogous with such package travel arrangements regulated by Directive 90/314 EC. Given the duration of the voyage and the inclusion of accommodation within the price, the Grand Chamber was satisfied that the contract was a 'package travel contract' for the jurisdiction of the Austrian courts to be effective under article 15(3). With regard to the second issue, the ECJ affirmed that the 'consistency with Regulation...' 19 necessitated two conditions. The first condition is the requirement to apply the 'concept of directed activity' and the second that the concept is 'interpreted harmoniously' both to ensure its consistent application between the Member States and the ability for it to reflect developments in technology. The Court confirmed that the key issue with the first condition is whether a business 'intended' to 'target' ${ }^{20}$ by doing business ${ }^{21}$ with consumers in different Member States, rather than simply falling foul of article 15 by virtue of 'mere accessibility' 22 of their web site to 'market goods or services' 23 to those consumers. The second key issue is whether, having intended to target consumers, the business actually has entered into a contract with consumers as a consequence. ${ }^{24}$ To be able to answer the second question, the Grand Chamber affirmed that Member States' national courts would have to take into account such cumulative matters as, but not limited to, the 'international nature of the [trader's] activity,' ${ }^{25}$ which could be exhibited by the existence of a top-level domain in addition to country-specific domains. Other factors the

\footnotetext{
18 See (n 3).

${ }^{19}$ Judgment of the Court (Grand Chamber) C-585/08 and C-144/09, 7 December 2010, para 11.

20 ibid para 64 ; on targeting see Gillies (n 1) generally and 204 ff.

${ }^{21}$ ibid para 92, despite an acknowledgement that the European Parliament's earlier (rejected) proposal that a business would have to have 'purposefully directed activity ...' analogous to a purposeful availment criteria in determining specific personal jurisdiction in a US state ; Gillies (n 1) $158 \mathrm{ff}$.

22 ibid para 69-70; following the US position derived from Asahi Metal Industry Co v Superior Court 480 US 102, 109, 107, S.Ct. 1026, 103394 L.Ed.2d.92 (1987); cf ALS Scan v Digital Service Consultants Inc, 293 F.3d 707 (4 $4^{\text {th }}$ Cir, 2002).

23 ibid para 73 .

24 ibid at para 76; in accordance with the requirement of art 15(1)(c).

25 ibid at para 93 . Word added for syntax.
} 
Court referred to included reference to the locations of branches, agencies or franchises where the business or its goods or services are available. Given the existing operation of article 15(2), this would only be relevant if the proposed replacement to Brussels I were to remove the requirement for a branch or agency in an EU Member State. The Court also referred to the language and currency options other than those used by the business and international telephone number options on its website and whether the business makes its details available via online business search directories used by consumers in different jurisdictions. ${ }^{26}$ The Court confirmed that what is necessary for the purposes of article 15(1)(c) is more evidence than the information requirements set out in Directive 2000/31 EC (the E-Commerce Directive) as a means of regulating information society services. Given the different approach of these instruments - 'Country of Destination' and 'Country of Origin' respectively ${ }^{27}$ - and the fact that in accordance with Recital 23, the E-Commerce Directive has never sought to regulate or provide additional rules of private international law, this is the correct approach.

\section{G. Concluding Observations}

Whilst the decision is respected and welcomed, at least one key question remains. Why, having provided the necessary criteria, did the Advocate General and the Grand Chamber take the view that it is for the national courts to ultimately determine the basis upon which article 15 of the Brussels 1 Regulation operates? In the interests of facilitating an autonomous interpretation and in particular the special basis upon which the consumer's jurisdiction is warranted, these cases were an ideal opportunity for the threshold upon the alternative basis upon which article 15(1)(c) operates to be precisely clarified. In conclusion, two key points emerge from both the Advocate General's opinion and the Grand Chamber's ruling. First, despite the aim for uniformity, it is for the courts of the Member State to determine whether the activities were directed to consumers in that Member State using the criteria provided by the CJEU. One wonders if reference back to the national court will provide a consistent approach to the interpretation of 'Europeanised' conflicts rules whilst at the same time observing developments towards the maximisation of consumer protection. If there was ever a connecting factor that merited an autonomous interpretation from the CJEU, the connecting factor 'directing activities' qualified as such. Second, despite contrary opinions contained in the Statement on article 15/73 and Recital 24 of the Rome I Regulation, in particular the language of a web site, the domain name(s) used by a business and the extent of any ringfencing are factors a national court can and must now take into account when assessing the degree of alignment between a foreign business' online commercial activities and a consumer contract for the purposes of article 15(1)(c). If the proposal for the replacement of the Brussels I Regulation is implemented as currently proposed to, inter alia, extend to matters currently falling within the remit of Member States' residual jurisdiction, the role of the national court in determining the scope of the special rule of jurisdiction in article 15(1)(c) is likely to have greater significance to businesses targeting EU consumers via websites in the future.

DR LORNA GILLIES*

\footnotetext{
26 ibid.

${ }^{27}$ See generally S Dutson, 'E-Commerce-European Union Transnational E-Commerce,' (2000) 16 CSLR 105 and P Stone, 'Internet Consumer Contracts and European Private International Law' (2000) 9 Information and Communications Technology Law 1, 5.

* School of Law, University of Leicester
} 
